\title{
KECERDASAN EMOSI DAN STRES AKADEMIK MAHASISWA: PERAN JENIS KELAMIN SEBAGAI MODERATOR DALAM SEBUAH STUDI EMPIRIK DI UNIVERSITAS PARAMADINA
}

\author{
Ayu Dwi Nindyati \\ Program Studi Psikologi, Universitas Binawan \\ Jl. Kalibata Raya - Dewi Sartika 13630 D.K.I. Jakarta, Indonesia D.K.I. Jakarta, Indonesia \\ Email: nindyati@binawan.ac.id
}

\begin{abstract}
ABSTRAK
Stres akademik merupakan fenomena yang sering dijumpai pada mahasiswa, termasuk di Universitas Paramadina. Sama halnya stres pada umumnya, stres akademik mahasiswa dapat dikelola ketika individu memiliki kecerdasan emosi yang bagus. Reaksi emosi laki-laki dan perempuan terhadap situasi yang menekan juga berbeda. Tujuan penelitian ini dilakukan adalah untuk mengetahui apakah jenis kelamin berperan sebagai moderator pada hubungan kecerdasan emosi dengan stres akademik mahasiswa di Universitas Paramadina. Alat ukur yang digunakan adalah alat ukur kecerdasan emosi yang telah digunakan oleh Dharmasoeka pada penelitian sebelumnya dengan menggunakan aspek-aspek dari Goleman (2015) dan alat ukur Educational Stress Scale for Adolescents (ESSA) yang disusun oleh Dunne dkk. (2010) untuk mengukur stres akademik. Penelitian ini dilakukan pada 108 mahasiswa (laki-laki $=65$ dan perempuan $=43$ ). Metode analisis yang digunakan untuk menetapkan jenis kelamin sebagai moderator dilakukan dengan menggunakan metode analisis yang dikemukakan oleh Baron \& Kenny. Hasil penelitian menunjukkan bahwa jenis kelamin tidak berperan sebagai variabel moderator pada pengaruh kecerdasan emosi terhadap stres akademik mahasiswa. Dari hasil penelitian ini juga diperoleh informasi bahwa kecerdasan emosi dan jenis kelamin memberikan pengaruh yang sangat signifikan terhadap stres akademik mahasiswa secara langsung.
\end{abstract}

Kata kunci: kecerdasan emosi; jenis kelamin; stres akademik mahasiswa; moderator

\section{EMOTIONAL INTELLIGENCE AND STUDENTS'ACEDEMIC STRESS: GENDER AS MODERATOR IN AN EMPIRICAL STUDY AT UNIVERSITAS PARAMADINA}

\begin{abstract}
Academic stress is a phenomenon that is often encountered on students, including students of Universitas Paramadina. Students' academic stress can be expelled by using log intelligence. Gender is also one of the factors that can potentially influence the relationship of intelligence with students' academic stress. The aim of this research is to know whether gender serves as a moderator in the relationship of emotional intelligence with students' academic stress at Universitas Paramadina. This study was conducted on 108 respondents (males $=65$ and females $=43$ ). Researchers used a measuring tool that was used on previous research by Dharmasoeka, together with aspects of Goleman (2015) and Educational Stress Scale for Adolescents (ESSA) measuring tool which was compiled by Dunne et al. (2010) to measure academic stress. The analysis method used to determine whether gender serves as a moderator in the relationship of emotional intelligence with students' academic stress is the method that was proposed by Baron \& Kenny (1986). The results indicate that gender does not serve as a moderator in the relationship of emotional intelligence with students' academic stress at Universitas Paramadina. This research shows that gender and emotional intelligence have direct effect on students' academic stress.
\end{abstract}

Keywords: emotional intelligence; gender; students' academic stress; moderator 


\section{PENDAHULUAN}

Dalam dunia perkuliahan, IP (Indeks Prestasi) merupakan indikator utama untuk menentukan kemampuan mahasiswa. Oleh karena itu, mahasiswa sering merasa cemas apabila nilai atau IP yang diperoleh tidak sesuai dengan yang diinginkan. Hal ini sesuai dengan hasil penelitian yang dilakukan oleh Efthim, Kenny, \& Mahalik (2001) bahwa harapan mahasiswa untuk mendapatkan nilai yang baik dalam pengerjaan tugas atau ujiannya sangat memengaruhi mahasiswa dalam bereaksi terhadap stres. Nuran \& Nazam (2008) mengatakan bahwa mahasiswa adalah salah satu kelompok di masyarakat yang memiliki stres tinggi, dan stres yang dirasakan mahasiswa pada umumnya merupakan stres akademik.

Menurut Govaerts \& Gregoire (2004), stres akademik adalah keadaan di mana mahasiswa mengalami tekanan sebagai hasil dari persepsi dan penilaian mengenai penyebab stres akademik yang berhubungan dengan ilmu pengetahuan dan pendidikan di perguruan tinggi. Penyebab dari stres akademik meliputi adanya harapan yang tinggi dalam mendapatkan nilai yang baik, perasaan tidak dihargai oleh teman ataupun dosen, tugas yang padat dengan kegiatan di luar akademik, tuntutan dari dosen yang saling bertentangan dengan diri sendiri, dan juga batas waktu yang sempit dalam mengumpulkan tugas perkuliahan (Desmita, 2010).

Menurut Yusuf (dalam Azmy, Nurihsan, \& Yudha, 2017), ketika mahasiswa mengalami stres, akan muncul empat reaksi yang terdiri dari: 1) reaksi fisik yang ditandai dengan kesulitan tidur dan sakit kepala; 2) reaksi emosional yang ditandai dengan kemunculan perasaan seperti kecemasan dan ketidakpuasan; 3) reaksi perilaku yang ditandai dengan perilaku membolos dan berperilaku agresif, serta; 4) reaksi proses berpikir yang ditandai dengan kesulitan berkonsentrasi.

Peneliti kemudian melakukan wawancara dengan tujuan untuk memperkuat fenomena stres akademik. Dari hasil wawancara yang telah dilakukan kepada seorang mahasiswi dan seorang mahasiswa, dapat diketahui bahwa terdapat kesamaan yang dialami oleh kedua mahasiswa tersebut, yaitu mahasiswi RG dan mahasiswa SA mengalami stres akademik yang disebabkan karena beban tugas yang padat dan batas waktu dalam pengumpulan tugas. Hal ini sejalan dengan penelitian Agolla \& Ongori (2009) yang menyebutkan bahwa beban tugas yang padat dan batas waktu pengumpulan tugas merupakan penyebab stres akademik. Dari penelitian Agolla \& Ongori tersebut, dijelaskan bahwa efek yang dirasakan oleh mahasiswa sebagai akibat dari stres akademik adalah gangguan pencernaan, mengalami kecemasan, nyeri pada leher atau bahu, sakit kepala, sesak nafas, sulit berkonsentrasi, dan terbayang-bayang oleh permasalahan yang sedang dialami.

Stres akademik yang tinggi dengan efek berupa gangguan fisik dapat memberikan pengaruh buruk pada mahasiswa, termasuk prestasi akademiknya. Untuk mengurangi dampak stres tersebut, diperlukan kemampuan untuk mengendalikan emosi dalam situasi tertekan atau tidak menyenangkan. Kemampuan mengelola stres memungkinkan individu untuk dapat menelaah permasalahan dengan tepat dan akan memudahkannya untuk memecahkan masalah dalam situasi tertekan (Nindyati, 2009). Menurut Goleman (2003), kecerdasan emosi merupakan kemampuan individu dalam mengelola perasaan atau emosinya dengan tepat atau selaras, sehingga individu mampu mencapai keseimbangan dalam dirinya. Dalam perkembangannya, Goleman (2015) juga menjelaskan kecerdasan emosi sebagai kemampuan untuk mengendalikan diri sendiri dan memiliki daya tahan ketika menghadapi rintangan, mengendalikan impuls, dan tidak merasa cepat puas pada apa yang telah dicapai. Bagi mahasiswa, kecerdasan emosi mampu memotivasi diri untuk lebih optimis dalam menyelesaikan setiap permasalahan akademis dan cenderung memiliki pandangan yang positif dalam menilai segala sesuatu yang terjadi pada dirinya (Goleman, 2015).

Penelitian Kartika (2015) juga mendukung bahwa kecerdasan emosi dan stres akademik memiliki hubungan negatif yang signifikan, artinya semakin tinggi kecerdasan emosi, maka akan semakin rendah stres akademik mahasiswa, dan begitu pula sebaliknya. Hasil penelitian lain juga menginformasikan bahwa kecerdasan emosi juga dipengaruhi oleh jenis kelamin (Goleman, 2015). Lebih lanjut, Goleman mengatakan bahwa laki-laki yang memiliki kecerdasan emosi tinggi akan mudah bersosialisasi, mudah bergaul, humoris, serta tidak mudah takut atau gelisah. Sementara itu, perempuan yang memiliki kecerdasan emosi tinggi cenderung bersikap tegas dan mengungkapkan perasaannya secara langsung, memandang dirinya secara positif, mudah bergaul, dan ramah. Perbedaan reaksi kecerdasan emosi pada laki-laki dan perempuan juga dapat dilihat dari segi motorik (Wang dkk., 2007) dan hormon (Asiyah, 2010).

Selanjutnya, penelitian yang dilakukan Siwi, Luthfi, \& Pradana (2011) menunjukkan bahwa perempuan memiliki kecerdasan emosi yang lebih tinggi daripada laki-laki. Hal ini membuktikan bahwa terdapat perbedaan yang signifikan pada kecerdasan berdasarkan jenis kelamin. Tetapi, penelitian yang dilakukan Siwi dkk. tidak selaras dengan hasil penelitian Nugroho dan Dwiyanti (2016) yang menunjukkan bahwa laki-laki memiliki tingkat kecerdasan emosi yang lebih tinggi dibandingkan 
perempuan. Selain itu, peneliti juga melihat bahwa terdapat beberapa hasil penelitian yang menginformasikan bahwa reaksi stres akademik pada laki-laki dan perempuan berbeda. Penelitian Calvarese (2015) menunjukkan bahwa perempuan mengalami reaksi stres yang lebih tinggi daripada laki-laki, sedangkan penelitian Kai-Wen (2009) menunjukkan bahwa laki-laki dalam konteks akademik memiliki stres yang lebih tinggi. Perbedaan reaksi stres antara laki-laki dan perempuan juga dapat dilihat dari segi strukur otak (Santrock, 2008) dan hormon (Wade \& Tavris, 2007).

Berdasarkan teori dan penelitian sebelumnya tentang kecerdasan emosi, stres akademik, dan jenis kelamin, peneliti melihat adanya peluang penempatan jenis kelamin sebagai moderator. Hal ini dilandasi oleh prinsip penerapan moderator pada penelitian Baron \& Kenny (1986). Lebih lanjut, Baron \& Kenny (dalam Nindyati \& Iskandar, 2009) menjelaskan bahwa keberadaan variabel ketiga yang berperan pada jalannya korelasi antara variabel bebas (X) dan variabel terikat $(\mathrm{Y})$ memiliki peluang untuk menjadi moderator. Variabel moderator pada umumnya memengaruhi hubungan $\mathrm{X}$ dan $\mathrm{Y}$ melalui dua tipe, yaitu: 1) merubah arah korelasi/peran X terhadap Y; 2) menguatkan/melemahkan peran $\mathrm{X}$ terhadap $\mathrm{Y}$. Berdasarkan penelitian sebelumnya (Govaerts \& Gregoire, 2004; Agolla \& Ongori, 2009; Calvarese, 2015), peneliti menemukan hasil bahwa terdapat korelasi antara kecerdasan emosi dengan stres akademik mahasiswa. Di satu sisi, terdapat variabel lain yang memperlihatkan bukti ilmiah bahwa jenis kelamin memiliki reaksi kecerdasan emosi yang berbeda dan reaksi terhadap stres akademik yang juga berbeda. Dengan demikian, secara konseptual, jenis kelamin memiliki peluang dalam merubah arah korelasi kecerdasan emosi dengan stres akademik, yang mana sebelum melibatkan jenis kelamin, arah korelasinya adalah positif, sementara ketika melibatkan jenis kelamin, arah korelasi berubah menjadi negatif.

Dengan memperhatikan teori, hasil penelitianpenelitian dari Govaerts \& Gregoire (2004), Agolla \& Ongori (2009), Kai-Wen (2009), Calvarese (2015), Siwi dkk. (2011), dan Nugroho \& Dwiyanti (2016), serta fenomena yang ada, maka peneliti memahami bahwa kecerdasan emosi pada mahasiswi memperlihatkan hubungan yang negatif dengan stres akademik. Dengan kata lain, semakin bagus kecerdasan emosi pada mahasiswi, maka semakin kecil stres akademik yang dirasakannya. Hal ini didukung oleh mayoritas hasil penelitian yang memberikan informasi bahwa perempuan lebih memiliki kemampuan untuk tetap tenang dalam menghadapi situasi-situasi yang menekan. Perempuan juga lebih mampu menahan emosi sehingga tidak terlarut dalam stres, serta mampu memotivasi dirinya sehingga tetap fokus pada impian walaupun telah mengalami kegagalan (Goleman, 1995). Sebaliknya, mahasiswa laki-laki cenderung mengalami stres akademik karena kecerdasan emosinya cenderung tidak kuat. Hal ini dikarenakan laki-laki pada umumnya lebih sulit mengelola reaksi emosinya ketika menghadapi hal-hal yang tidak sesuai dengan keinginannya, khususnya pada situasi yang sulit dalam menghadapi banyaknya tugas-tugas akademis (Kauts, 2018). Reaksi emosi mahasiswa cenderung lebih agresif dan kurang mampu menjaga reaksi emosinya dalam menanggapi suatu permasalahan maupun ketika berada dalam situasi yang menekan. Berdasarkan logika yang dilandasi teori, hasil penelitian, dan fenomena penelitian, peneliti melihat bahwa jenis kelamin dapat berperan sebagai moderator pada hubungan kecerdasan emosi dengan stres akademik mahasiswa. Hal ini ditunjang dengan adanya penelitian Siwi dkk. (2011) dan Nugroho \& Dwiyanti (2016) yang menyatakan bahwa peran jenis kelamin terhadap kecerdasan emosi berbeda. Siwi dkk. menyatakan bahwa perempuan memiliki kecerdasan emosi yang lebih tinggi, sementara Nugroho \& Dwiyanti menyatakan bahwa laki-laki yang lebih tinggi kecerdasan emosinya. Berdasarkan uraian tersebut, maka dirumuskan hipotesis penelitian sebagai berikut.

$\mathrm{H}_{\mathrm{a}}$ : Jenis kelamin dapat berperan sebagai moderator pada hubungan kecerdasan emosi dengan stres akademik mahasiswa/i di Universitas Paramadina.

\section{METODE}

Penelitian ini menggunakan pendekatan kuantitatif dengan desain penelitian noneksperimen. Penelitian ini dilakukan dalam setting alamiah tanpa memberikan perlakuan tertentu pada subjek penelitian untuk mendapatkan gambaran setiap variabel penelitiannya (Creswell, 2013). Populasi dalam penelitian ini adalah mahasiswa/i Universitas Paramadina dengan rentang usia 18 sampai 25 tahun. Pemilihan sampel harus memenuhi asas representasi, salah satunya dengan menggunakan teknik sampling tertentu untuk mendapatkan sampel. Pada penelitian ini, peneliti menggunakan subjek penelitian sebesar $10 \%$ dari populasi. Hal ini sesuai dengan pendapat Arikunto (2010), bahwa apabila subjek kurang dari 100, maka lebih baik diambil semua sehingga penelitiannya merupakan populasi. Tetapi, jika jumlah subjek lebih dari 100, maka dapat diambil antara 10 $15 \%$ atau 15 - 25\% atau lebih. Dengan demikian, jumlah responden pada penelitian ini adalah sebanyak 108 mahasiswa/i. Dengan mengikuti ketentuan 
besaran persentase dalam mendapatkan jumlah sampel penelitian, maka responden penelitian ini dapat dikatakan representatif. Sementara itu, untuk mendapatkan orang yang bersedia menjadi sampel, digunakan teknik sampling berupa convenience nonprobability sampling. Cresswell (2013) menjelaskan bahwa apabila peneliti tidak memiliki informasi yang pasti terkait anggota populasi, maka dapat menggunakan teknik non-probability sampling. Salah satu teknik non-probability sampling yang disarankan adalan convenience sampling. Pada convenienceprobability sampling ini, setiap orang yang dipilih menjadi sampel akan diberikan kesempatan untuk menyatakan dirinya bersedia menjadi sampel penelitian atau tidak, sehingga hal ini menjadi semacam informed consent kesediaan untuk menjadi sumber data penelitian. Dengan memperhatikan cara pengambilan sampel yang dilakukan dalam penelitian ini, maka dapat disimpulkan bahwa pengambilan sampel yang dilakukan adalah dengan menggunakan teknik proportional convenience non-probability sampling.

Pengambilan data dilakukan dengan menggunakan kuesioner pada setiap variabel penelitian. Pengukuran yang digunakan untuk variabel stres akademik adalah alat ukur Educational Stress Scale for Adolesecent (ESSA) yang terdiri dari 17 pernyataan dan telah diterjemahkan ke dalam bahasa Indonesia serta diterbitkan oleh Dunne dkk. (2010). Dunne dkk. (2010) menjelaskan bahwa ada lima komponen yang dijadikan dasar pembuatan pernyataan pada pengukuran stres akademik, yaitu tekanan dalam belajar, beban tugas, perasaan khawatir terhadap nilai, harapan diri, dan keputusasaan.

Untuk variabel kecerdasan emosi, dilakukan pengukuran dengan alat ukur kecerdasan emosi yang telah digunakan oleh Dharmasoeka (dalam Nindyati, 2009) pada penelitian sebelumnya dengan menggunakan aspek-aspek dari Goleman (2015), yaitu kesadaran diri, pengaturan diri, motivasi diri, empati, dan keterampilan sosial. Penelitian ini menggunakan skala model Likert. Penentuan nilai skala berdasarkan pada distribusi respon pernyataan sikap. Sifat pernyataan dalam alat ukur ini dibagi menjadi dua, yaitu pernyataan favorable (yang bersifat mendukung kepada objek yang diukur) dan pernyataan unfavorable (yang bersifat tidak mendukung kepada objek yang diukur) (Azwar, 2011).

Alat ukur yang digunakan dalam penelitian ini telah melalui uji coba, sehingga didapatkan konfirmasi pernyataan bahwa alat ukur ini dapat digunakan. Berdasarkan uji coba alat ukur, diperoleh informasi koefisien reliabilitas untuk alat ukur kecerdasan emosi sebesar 0,892, sedangkan nilai koefisien reliabilitas untuk alat ukur stres akademik (ESSA) adalah sebesar 0,899 . Untuk menentukan item yang dapat digunakan dalam penelitian, digunakan standar yang dikemukakan oleh Kaplan \& Sacuzzo (2013) bahwa item yang bagus adalah item yang memiliki skor itemtotal correlation di atas 0,30. Terdapat 6 item kecerdasan emosi yang memiliki nilai item-total correlation kurang dari 0,30, yaitu item $1(0,138)$, item $8(0,288)$, item $13(0,214)$, item $16(0,246)$, item 25 $(0,252)$, dan item $30(0,160)$. Item-item tersebut tidak akan disisihkan, melainkan diperbaiki kalimat pernyataannya agar mudah dipahami. Sedangkan pada uji coba alat ukur stres akademik (ESSA), seluruh item memiliki nilai koefisien item-total correlation lebih dari 0,30, sehingga alat ukur kecerdasan emosi dan alat ukur stres akademik (ESSA) akan tetap digunakan dalam pengambilan data penelitian.

Setelah uji coba alat ukur dilakukan, maka dilakukan uji analisis alat ukur kembali atas data penelitian. Hasil uji reliabilitas dengan Cronbach's alpha menunjukkan hasil koefisien $\alpha$ alat ukur stres akademik adalah sebesar 0,949 dan koefisien $\alpha$ kecerdasan emosi sebesar 0,895. Berdasarkan hasil tersebut, dapat dikatakan bahwa kedua alat ukur tersebut memiliki reliabilitas yang baik dan dapat digunakan. Menurut Anastasi \& Urbina (2006), koefisien reliabilitas yang baik dan dapat diterima berkisar antara 0,6 sampai 0,8, sehingga alat ukur dalam penelitian ini bisa dikatakan dapat diandalkan.

Untuk menguji hipotesis penelitian yang diajukan, peneliti menggunakan pendekatan uji moderator yang disampaikan oleh Baron \& Kenny (1986), dengan desain yang terlihat pada Gambar 1.

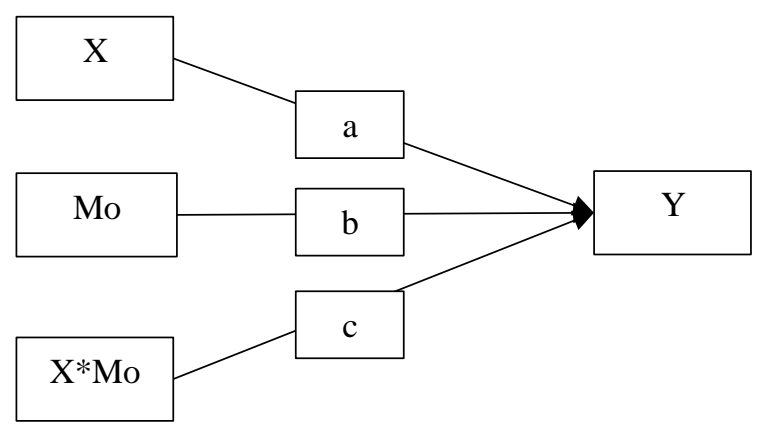

\section{Gambar 1. Model Analisis Variabel Moderasi}

Terdapat tiga syarat dalam memenuhi kriteria variabel moderator, yaitu:

a. Jika variabel bebas $(\mathrm{X})$ berkorelasi dengan variabel terikat (Y);

b. Jika variabel bebas (X) berkorelasi dengan variabel moderator (Mo), dan;

c. Jika variabel Mo*X (produk) berkorelasi dengan variabel terikat (Y) 
Dengan memenuhi tiga syarat tersebut, maka penelitian dapat menggunakan variabel moderator. Pada penelitian ini, data yang diperoleh dianalisis menggunakan teknik statistika analisis varian dua jalur (multiple analysis varians) untuk dapat melihat hasil korelasi produk (interaksi Mo dan IV) terhadap DV. Alasan digunakannya analisis varian adalah karena variabel moderator (Jenis Kelamin) memiliki data berbentuk nominal. Efek moderasi secara statistik ditandai dengan signifikansi peran variabel produk terhadap variabel dependen, dengan catatan bahwa jalur a dan b juga signifikan terhadap variabel terikat (Nindyati \& Iskandar, 2009; Baron \& Kenny, 1986).

\section{HASIL DAN PEMBAHASAN}

Tabel 1. Nilai Rata-rata Stres Akademik Mahasiswa
Analisis deskriptif menginformasikan jumlah responden sebesar 108 (Laki-laki $=65$; Perempuan $=$ 43). Jumlah responden laki-laki dan perempuan yang berbeda ini terjadi sesuai dengan hasil pengumpulan data yang memperhatikan kesediaan sampel dalam mengikuti penelitian ini. Jenis data kecerdasan emosi dikategorikan menjadi kecerdasan emosi di atas ratarata dan di bawah rata-rata. Jumlah responden berdasarkan kecerdasan emosi $(\mathrm{M}=159,78)$, di atas rata-rata adalah sebanyak 55 orang (laki-laki $=37$ dan perempuan $=18$ ), sementara jumlah responden dengan kecerdasan emosi di bawah rata-rata sebanyak 53 orang (laki-laki $=28$ dan perempuan $=25$ ). Pada Tabel 1, dapat diketahui informasi rata-rata stres akademik pada kelompok laki-laki dan perempuan, serta kelompok kecerdasan emosi tinggi (di atas rata-rata) dan rendah (di bawah rata-rata).

\begin{tabular}{|c|c|c|c|c|c|c|c|c|}
\hline \multirow[t]{2}{*}{ Variabel } & \multirow[t]{2}{*}{ Lelaki } & \multirow{2}{*}{$\begin{array}{l}\text { Perem- } \\
\text { puan }\end{array}$} & \multirow{2}{*}{$\begin{array}{l}\text { KE* } \\
\text { tinggi }\end{array}$} & \multirow{2}{*}{$\begin{array}{c}\text { KE ren- } \\
\text { dah }\end{array}$} & \multicolumn{2}{|c|}{ Laki-laki } & \multicolumn{2}{|c|}{ Perempuan } \\
\hline & & & & & $\begin{array}{c}\text { KE } \\
\text { tinggi }\end{array}$ & $\begin{array}{c}\text { KE ren- } \\
\text { dah }\end{array}$ & $\begin{array}{c}\text { KE } \\
\text { ting } \\
\text { gi }\end{array}$ & $\begin{array}{c}\mathrm{KE} \\
\text { rendah }\end{array}$ \\
\hline $\begin{array}{l}\text { Stres akade- } \\
\text { mik maha- } \\
\text { siswa }\end{array}$ & 32 & 38,7 & 31,3 & 38,1 & 29,5 & 35,4 & 35,2 & 41 \\
\hline
\end{tabular}

$* \mathrm{KE}=$ Kecerdasan emosi

Dapat dilihat pada Tabel 1 bahwa skor rata-rata stres akademik mahasiswi lebih tinggi dibandingkan skor rata-rata stres akademik mahasiswa. Di samping itu, skor rata-rata stres akademik pada kelompok dengan kecerdasan emosi tinggi lebih kecil dibandingkan dengan kelompok yang memiliki kecerdasan emosi rendah. Secara lebih detail, dijelaskan juga bahwa laki-laki dan perempuan dengan kecerdasan emosi tinggi memiliki nilai ratarata stres akademik yang tidak jauh berbeda, sedangkan untuk untuk kelompok laki-laki dan perempuan dengan kecerdasan emosi rendah, nilai rata-rata stres akademiknya menunjukkan perbedaan yang lebih besar, yaitu dengan skor d (mean difference) sebesar 5,99.
Uji hipotesis penelitian dilakukan dengan menggunakan analisis varian dua jalur, untuk mengetahui apakah jenis kelamin berperan sebagai moderator pada pengaruh kecerdasan emosi terhadap stres akademik mahasiswa. Hasil analisis data dapat dilihat pada Tabel 2 .

Tabel 2. Hasil Analisis Varian Dua Jalur terhadap Stres Akademik

\begin{tabular}{lcc}
\hline \multicolumn{1}{c}{ Sumber } & $\mathbf{F}$ & $\mathbf{p}$ \\
\hline Jenis Kelamin & 8,680 & $0,004^{* *}$ \\
Kecerdasan & 9,264 & $0,003^{* *}$ \\
Emosi & & \\
Jenis Kelamin x & 0,001 & 0,981 \\
Kecerdasan & & \\
Emosi & & \\
\hline$* * \mathrm{p}<0,01$ & &
\end{tabular}


Berdasarkan Tabel 2, dapat diperoleh gambaran pada diagram sebagai berikut:

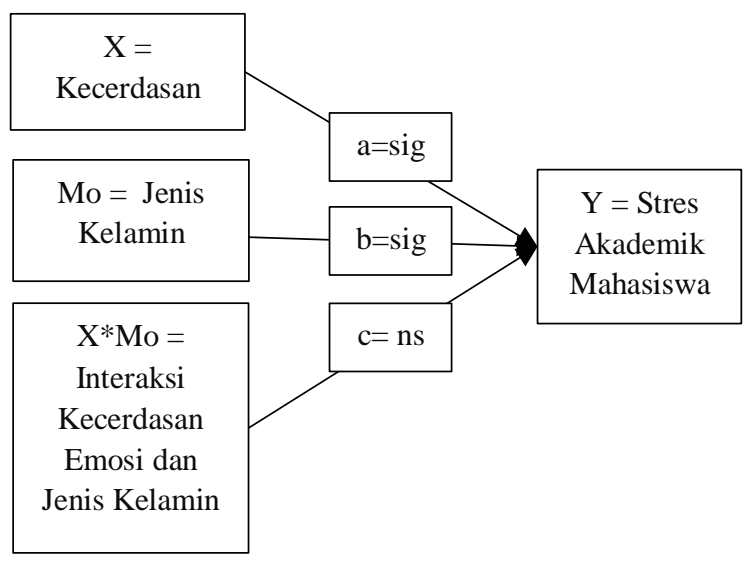

\section{Gambar 2. Hasil Analisis Varian (Uji Hipotesis)}

Gambar 2 menjelaskan bahwa jalur a dan b (siginifikan) memenuhi kriteria untuk menetapkan ada atau tidaknya efek moderasi, namun karena jalur c tidak terbukti signifikan, maka hipotesis yang diajukan dalam penelitian ini tidak terkonfirmasi. Dengan demikian, dapat disimpulkan bahwa jenis kelamin tidak berperan sebagai variabel moderator pada pengaruh kecerdasan emosi terhadap stres akademik mahasiswa. Dari hasil penelitian ini juga diperoleh informasi bahwa kecerdasan emosi dan jenis kelamin memberikan pengaruh yang sangat signifikan terhadap stres akademik mahasiswa secara langsung.

Tujuan utama penelitian ini adalah untuk mengetahui apakah jenis kelamin dapat berperan sebagai moderator pada hubungan antara kecerdasan emosi dengan stres akademik mahasiswa. Setelah dilakukan analisis moderasi dengan menggunakan analisis model moderasi yang dikemukakan oleh Baron \& Kenny (Nindyati \& Iskandar, 2009), maka disimpulkan bahwa hipotesis yang diajukan tidak terkonfirmasi. Hasil penelitian menunjukkan bahwa jenis kelamin tidak berperan sebagai moderator pada hubungan antara kecerdasan emosi dengan stres akademik mahasiswa.

Hasil penelitian ini selaras dengan hasil penelitian yang dilakukan Kauts (2016) bahwa pengaruh kecerdasan emosi terhadap stres akademik mahasiswa adalah signifikan sebelum menempatkan jenis kelamin sebagai variabel moderator. Hal ini menjelaskan bahwa jenis kelamin tidak akan merubah arah ataupun menguatkan peran kecerdasan emosi dengan stres akademik mahasiswa.

Hasil lain yang dapat diperoleh dari penelitian ini adalah diketahui bahwa jenis kelamin dan kecerdasan emosi berperan terhadap stres akademik secara langsung, yang artinya stres akademik pada mahasiswa dengan kecerdasan emosi tinggi dan rendah berbeda secara signifikan (jalur a). Stres kerja akademik juga berbeda secara signifikan pada mahasiswa laki-laki dan perempuan (jalur b). Hasil penelitian ini menguatkan hasil penelitian yang dilakukan oleh Kauts (2018) terkait dengan kecerdasan emosi dan stres pada siswa laki-laki dan perempuan. Hasil penelitian Kauts (2018) menjelaskan adanya stres yang lebih kuat pada kelompok perempuan dibandingkan dengan kelompok laki-laki. Demikian juga terkait dengan kecerdasan emosi, bahwa kelompok yang memiliki kecerdasan emosi tinggi memperlihatkan stres akademik yang lebih rendah dibandingkan dengan kelompok yang memiliki kecerdasan emosi rendah. Sementara itu, secara lebih rinci dijelaskan bahwa pada kelompok mahasiswa laki-laki dengan tingkat kecerdasan emosi tinggi, stres akademiknya cenderung lebih rendah dibandingkan laki-laki dengan tingkat kecerdasan emosi rendah. Hal ini berlaku juga pada kelompok subjek penelitian perempuan.

Penelitian terkait dengan kecerdasan emosi yang dilakukan Goleman (1995) menjelaskan bahwa individu dengan kecerdasan emosi yang baik memiliki kapasitas dalam mengenali apa yang dirasakan terhadap dirinya sendiri dan orang lain. Hal tersebut merupakan faktor penting dalam memotivasi dan mengelola kondisi emosi kita, baik terkait diri kita sendiri maupun ketika berelasi dengan orang lain. Penelitian selanjutnya dari Goleman (2003) juga memperlihatkan bahwa kecerdasan emosi ini merupakan faktor penting dalam memprediksi kesuksesan pribadi, akademik, maupun karir. Dengan memahami apa yang disampaikan oleh Goleman, maka dapat dijelaskan bahwa hasil penelitian ini memberikan penguatan terhadap peran kecerdasan emosi terhadap keberhasilan individu, terutama dalam bidang akademik. Kecerdasan emosi dalam penelitian ini memberikan penjelasan bahwa mahasiswa yang memiliki kecerdasan emosi yang baik merasakan stres akademik yang lebih kecil. Dengan semakin rendahnya stres akademik yang dirasakan, maka mahasiswa akan mampu mengoptimalkan kemampuannya untuk mencapai prestasi akademik secara lebih maksimal.

Berkaitan dengan jenis kelamin dan stres akademik, hasil penelitian ini juga menguatkan hasil penelitian yang dilakukan Dhull \& Kumari (2015). Dalam penelitian tersebut, dijelaskan bahwa stres akademik terlihat berbeda pada kelompok laki-laki dan kelompok perempuan. Kelompok perempuan menunjukkan stres akademik yang lebih besar dibandingkan pada kelompok laki-laki. Hal ini tidak terlepas dari faktor alamiah bahwa perempuan lebih sensitif dan lebih peka terhadap apa yang terjadi di 
sekitarnya. Kondisi ini juga membuat perempuan cenderung lebih menganggap semua hal yang terjadi dengan serius, berbeda dengan laki-laki yang terkadang cenderung menganggap enteng dan menunjukkan sikap yang easy going dalam menghadapi situasi yang ada.

Dengan memperhatikan proses dan hasil penelitian ini, maka terdapat beberapa hal yang dapat ditingkatkan untuk penelitian selanjutnya. Di antaranya adalah dengan mencoba menggunakan variabel moderator lain, seperti usia atau tahap perkembangan, karena setiap tahap perkembangan manusia memiliki tugas perkembangan yang berbeda dan tidak terlepas dari peran lingkungan sekitarnya.

\section{SIMPULAN}

Berdasarkan hasil penelitian yang diperoleh, maka dapat disimpulkan bahwa jenis kelamin tidak berperan sebagai variabel moderator pada hubungan kecerdasan emosi dengan stres akademik mahasiswa. Meskipun begitu, penelitian ini juga menunjukkan bahwa jenis kelamin dan kecerdasan emosi memiliki peran langsung terhadap munculnya stres akademik. Di samping itu, diperoleh informasi bahwa dilihat dari jenis kelaminnya, stres akademik perempuan lebih tinggi dibandingkan laki-laki. Dapat dijelaskan pula bahwa kelompok responden dengan kecerdasan emosi yang tinggi cenderung memperlihatkan stres akademik yang rendah.

Berdasarkan hasil penelitian, disarankan bagi mahasiswa perempuan, yang lebih rentan untuk mengalami stres akademik, untuk lebih mengelola kehidupan emosinya apabila berada dalam situasi yang tidak menyenangkan. Goleman (dalam Perwitasari, 1998) menyatakan bahwa perbedaan tingkatan flooding pada laki-laki dan perempuan membuat adanya reaksi emosi yang berbeda, di mana laki-laki cenderung diam, sementara perempuan akan lebih menyerang (talk active). Dengan kondisi ini, perempuan lebih banyak mengungkapkan emosi, yang mana jika tidak tepat dengan lingkungannya, maka akan berakibat menjadi stressor baru baginya, termasuk dalam hal akademik.

Menurut Mortiboys (2005), kecerdasan emosi ditempatkan sebagai inti dari keberhasilan dalam proses pembelajaran. Oleh karena itu, disarankan agar dosen selalu melatih dirinya dalam mengelola emosi negatif yang dapat memengaruhi penilaian (judgement), dapat bersikap proaktif, dan tidak reaktif. Berkaca dari penelitian yang dilakukan oleh Mortiboys, maka peneliti memahami bahwa ketika dosen menggunakan kecerdasan emosi dalam pembelajaran, maka secara tidak langsung dosen juga melibatkan dan meningkatkan kecerdasan emosi mahasiswanya dengan cara terus berinteraksi secara aktif untuk membangun motivasi mahasiswa dalam menghadapi setiap tuntutan akademik.

Dari penelitian ini, peneliti melihat masih adanya peluang untuk terus melakukan pengkajian terkait dengan stres akademik ini, terutama jika dikaitkan dengan tahapan perkembangan yang lebih spesifik. Karena apabila didasari pemahaman, setiap tahap perkembangan yang memiliki tugas perkembangan yang berbeda mungkin saja memberikan dinamika informasi yang berbeda pula, baik ketika mengalami stres akademik, maupun ketika memberikan respons terhadap stres akademik.

\section{DAFTAR PUSTAKA}

Agolla, J. E., \& Ongori, H. (2009). An assessment of academic stress among undergraduate students: The case of University of Botswana. Educational Research and Reviews, 4(2), 063-070.

Anastasi, A., \& Urbina, S. (2006). Psychological testing [Tes psikologi]. Jakarta: Indeks.

Arikunto, S. (2010). Prosedur penelitian: Suatu pendekatan praktik (Revisi). Jakarta: Rineka Cipta.

Asiyah, S. N. (2010). Belajar psikologi faal. Surabaya: IAIN Press.

Azmy, A. N., Nurihsan, A. J., \& Yudha, E. S. (2017). Deskripsi gejala stres akademik dan kecenderungan pilihan strategi koping siswa berbakat. Indonesian Journal of Educational Counseling, 1(2), 197-208. Retrieved from https://doi.org/10.30653/001.201712.14

Azwar, S. (2011). Tes prestasi: Fungsi dan pengembangan pengukuran prestasi belajar. Yogyakarta: Pustaka Pelajar.

Baron, R. M., \& Kenny, D. A. (1986). The moderatormediator variable distinction in social psychological research: Conceptual, strategic, and statistical considerations. Journal of Personality and Social Psychology, 51(6). https://doi.org/10.1037//0022-3514.51.6.1173

Bayram, N., \& Bilgel, N. (2008). The prevalence and socio-demographic correlations of depression, anxiety and stress among a group of university students. Social Psychiatry and Psychiatric Epidemiology, 43(8), 667-672. https://doi.org/10.1007/s00127-008-0345-x

Calvarese, M. (2015). The effect of gender on stress factors: An exploratory study among university students. Social Sciences, 4(4), 1177-1184. https://doi.org/10.3390/socsci4041177

Creswell, J. W. (2013). Research design: Qualitative, quantitative and mixed methods [Research 
design: Pendekatan kualitatif, kuantitatif dan mixed] (3rd ed.). Yogyakarta: Pustaka Pelajar.

Desmita. (2010). Psikologi perkembangan peserta didik. Bandung: Remaja Rosda Karya.

Dhull, I., \& Kumari, S. (2015). Academic stress among adolescents in relation to gender. International Journal of Applied Research, 1(11), 394-396.

Efthim, P. W., Kenny, M. E., \& Mahalik, J. R. (2011). Gender role stress in relation to shame, guilt, and externalization. Journal of Counseling \& Development, 79(4).

Goleman, D. (1995). Emotional intelligence. New York: Bantam Books.

Goleman, D. (2003). Emotional intelligence [Kecenderungan emosi untuk mencapai puncak prestasi] (Cetakan Ke-5). Jakarta: Gramedia Pustaka Utama.

Goleman, D. (2015). Emotional intelligence [Kecerdasan emosional: Mengapa EI lebih penting daripada IQ] (Cetakan Ke-8). Jakarta: Gramedia Pustaka Utama.

Govaerts, S., \& Grégoire, J. (2004). Stressful academic situations: Study on appraisal variables in adolescence. Revue Européenne de Psychologie Appliquée, 54(4), 261-271.

Kai-Wen, C. (2010). A study of stress sources among college students in Taiwan. Journal of Academic and Business Ethics, 2(1), 35-41.

Kaplan, R. M., \& Saccuzzo, D. P. (2013). Psychological testing: Principles, applications, and issues (8th ed.). Belmont, CA: Cengage Learning.

Kartika, C. D. (2015). Hubungan kecerdasan emosi dengan stres akademik mahasiswa Fakutas Psikologi Universitas Muhammadiyah Surakarta. Universitas Muhammadiyah Surakarta.

Kauts, D. S. (2016). Emotional intelligence and academic stress among college. Journal of Education and Applied Social Sciences, 7(3), 149-158. https://doi.org/10.5958/2230-
Kauts, D. S. (2018). Emotional intelligence in relation to stress on boys and girls at the secondary stage. MIER Journal of Educational Studies, Trends \& Practices, 8(1), 1-16.

Mortiboys, A. (2005). Teaching with emotional intelligence: A step-by-step guide for higher and further education professionals. Routledge.

Nindyati, A. D. (2009). Pengaruh resistance to change terhadap perilaku inovatif: Kecerdasan emosi sebagai mediator. Jurnal Universitas Paramadina, 6(1), 94-110.

Nindyati, A. D., \& Binawan, U. (2009). Penempatan model mediator dan moderator pada penelitian psikologi kepribadian. Jurnal Psikologi, 23(1). https://doi.org/10.13140/RG.2.1.2350.8964

Nugroho, S., \& Dwiyanti, R. (2016). Perbedaan kecerdasan emosi antara perawat laki-laki dan perawat perempuan. Psycho Idea, 14(2), 39-46. https://doi.org/10.30595/psychoidea.v14i2.2119

Prawitasari, J. E. (1998). Kecerdasan emosi. Buletin Psikologi, 6(1), 21-31.

Respati, W. S., Luthfi, A., \& Pradana, N. (2011). Perbedaan kecerdasan emosional ditinjau dari persepsi penerapan disiplin orangtua pada mahasiswa UIEU. Jurnal Psikologi, 9(1), 16-28.

Santrock, J. W. (2008). Educational psychology [Psikologi pendidikan] (2nd ed.). Jakarta: Kencana.

Sun, J., Minh, D., Nguyen, A., Thai, T. T., Chi, H., City, M., \& Dixon, J. (2010). The influence of educational pressure on the mental health of adolescents in East Asia: Methods and tools for research. Journal of Science, 61.

Wade, C., \& Tavris, C. (2007). Psychology [Psikologi] (9th ed.). Jakarta: Erlangga.

Wang, J., Korczykowski, M., Rao, H., Fan, Y., Pluta, J., Gur, R. C., ... Detre, J. A. (2007). Gender difference in neural response to psychological stress. Social Cognitive and Affective Neuroscience, 2(3), 227-239. https://doi.org/10.1093/scan/nsm018 